\title{
ERRATUM
}

\section{TO PUNISH THE PERSON: A READING NOTE REGARDING A PUNCTUATION MARK IN THE TSINGHUA MANUSCRIPT ${ }^{*} M I N G X U N-$ ERRATUM}

\author{
Edward L. Shaughnessy \\ https://doi.org/10.1017/eac.2017.15 Published by Cambridge University \\ Press, 12 October 2017.
}

Keywords: Tsinghua manuscripts, Yi Zhou shu, paleography, punctuation, reading practices,

清華簡,《逸周書》, 古文字學, 標點符號, 閱讀習慣

Following a correction to an article in a reprinted version of the latest issue of the journal, the article by Edward L. Shaughnessy ${ }^{1}$ has also been repaginated. The online issue has also been updated.

The publisher apologises to the author and readers for this error.

1. Edward L. Shaughnessy, "To Punish the Person: a reading note regarding a punctuation mark in the Tsinghua manuscript *Ming Xun," Early China 40 (2017), 303-309. https://doi.org/10.1017/eac.2017.15

(C) The Society for the Study of Early China and Cambridge University Press 2017 